\title{
STRUCTURAL POWER TOWARD WEAK STATES: FRANCE, NOT CHINA, MATTERS IN FRANCOPHONE AFRICA
}

\section{Olivier Mbabia ${ }^{1}$}

The magnitude of assignment of the People's Republic of China in Africa has recently ignited a tide of 'speedy' literature ranking the latter as the main actor to the detriment of traditional ones. A close look at this issue, however, shows that this deduction seems all the less simplistic. By deliberately limiting the present analysis to the so-called Francophone Africa $^{2}$, where Chinese engagement is as considerable as elsewhere on the continent, it appears that this conclusion is shaky when submitted to a rigorous analysis. Can a causal relation be established between the progression of this presence and Beijing's actual influence? Can power or influence be subsumed to an ever-growing presence and an economic vitality? Are these parameters enough to unseat old colonial powers, especially France in its original and natural area of influence?

A positive answer does not help explaining how can the authority and legitimacy meted by French leaders and institutions on governing elite and the populations be accounted for more than half a century after the physical

1 Researcher at Université de Montréal, Canada. Postdoctoral student at the same institution. E-mail: oliviermbabia@yahoo.com.

2 The expression "Francophone Africa" generally refers to those countries that have French as an official or a spoken language. In this study, the term is used to designate the countries of Sub-Saharan Africa that maintain exceptionally - abnormally in some cases - close political, cultural, economic and military relations with France, their former colonial power, namely: Benin, Burkina Faso, Central African Republic, Chad, Comoros, Republic of Congo, Djibouti, Gabon, Guinea, Ivory Coast, Madagascar, Mali, Mauritania, Niger, Senegal. Other countries are Cameroon and Togo, two former German protectorates transferred to France following the Treaty of Versailles in 1919. 
dismantling of the colonial empire. Some recent events illustrate this point. In 2009, the French response to Andry Rajoelina - who found shelter in the French embassy - coup in Madagascar was to normalize the de facto situation. In December 2012, "French cousins" were called for help by the Central African President in a bid to stop the progress of rebels towards Bangui ${ }^{3}$. In February 2013, a few weeks after the launching of the Serval Operation, the French Head of State was triumphal welcome in Mali. Many more manifestations of this type are depicted through the attraction towards television channels, the passion fed by the military parade on July $14^{\text {th }}$, the festive enthusiasm expressed in French presidential elections (especially that of May 2012 with the ousting of Nicholas Sarkozy) in Brazzaville, Libreville, Abidjan, Dakar or Douala.

This article seeks to explain the determinants of France influence compared to that of China in Francophone Africa. Focusing on the paradigm of structural power as theorized by Susan Strange, it will attempt to debunk any considerations of a "declining" French influence in Francophone Africa. It will be argued that the existence of "special relationships" manifested through close political and cultural ties but also through covert economic and military networks give onto France the potentials to determine the structure of the regional political economy, in which Francophone African States evolve (hypothesis). The first section discusses the debate on the definition of power. The next section compares the determinants and modalities of Chinese and French involvement based on the structures of security, finance, production and knowledge. The third section explores how the current configuration enables France to outrun China sustainably. Particular attention will be given to the issues and challenges of the French power in its natural zone of influence. Finally, in the conclusion, I underline that Chinese engagement in this region is even more "shallow" as far as it is bereft of content and intensity.

${ }^{3}$ François Bozizé said: "We are asking our cousins the French and the United States, which are major powers, to help us push back the rebels to their initial positions in a way that will permit talks in Libreville to resolve this crisis." See Valdmanis and Osborn, 2012. 


\section{Power and Structural Power}

Power is a general concept and, hence, less operational and very much debated. It remains a central issue in international relations - especially for the realists. Taking inspiration from the Weberian conception of power, defined as "any chance to impose one's will within a social relation, and even in the face of adversity", realists believe that power is essentially the expression of one actor's ability to get another to do what it would not otherwise have done through military threats. According to Aron, "power on the international setting is the ability of a political unit to impose one's will onto other units" 4 . This traditional conception of power is progressively put into question, especially by hegemonic realism, which had the merit of rethinking the definition of power conceived as a bundle of material capacities by realist theories. With this redefinition, power turns into 'hegemony', which imposes a reappraisal of instruments put at the disposal of great nations to exert their leadership. According to Robert Gilpin ${ }^{5}$ for instance, hegemony is not solely grounded into tangible capabilities. In other words, his definition of hegemony is half-way between the pure realistic conception of hegemony propounded by Mearsheimer who simply sees it as material supremacy, especially military supremacy, and the Gramscian theory which defines hegemony as a domination which is not felt as one by those who undergo it.

Steven Lukes' three-dimensional power conception ${ }^{6}$ is interesting in this regard. Lukes holds that power has three dimensions which were identified on the basis of works carried in previous works by Robert Dahl (one-dimensional view), Peter Bachrach and Morton Baratz (two-dimensional view ${ }^{7}$ ). For this author, the most paramount form of power is domination. With the threedimensional view, power can be observed where people are subject to domination and acquiesce in that domination. According to his definition of the concept of power, "A exercises power over B when A affects B in a manner

\footnotetext{
${ }^{4}$ Raymond Aron, Paix et Guerre entre les Nations (Paris: Calman-Lévy, 1962), 16-17.

${ }^{5}$ Robert Gilpin, The Political Economy of International Relations (Princeton: Princeton University Press, 1987).

${ }^{6}$ Steven Lukes, Power: A Radical View (London: Macmillan, 1974).

${ }^{7}$ Peter Bachrach and Morton S. Baratz, "The Two Faces of Power," American Political Science Review 56 (1962): 947-953.
} 
contrary to B's interest." 9 Thus, the three-dimensional view refers to the invisible power which consists in determining other actors' preferences. What matters is to prevent people from having grievances, by shaping their views and preferences in such a way that they accept their role within the social order, either because they cannot expect an alternative, or because they consider it natural and unchanging.

From quite a different perspective, the British scholar Susan Strange, who is a pioneer of International Political Economy, highlights that the weberian conception of power does not enable to satisfactorily account for international power relations in the contemporary world. She developed the concept of "structural power". "Structural power, on the other hand, is the power to shape and determine the structures of the global political economy within which other states, their political institutions, their economic enterprises and (not least) their scientists and other professional people have to operate." 9 She identified four sources: that of security, within which power is based on the capacity to supply someone with protection against threats and on the capacity to threaten someone's security; financial structure, which is related to offer, deny or ask for credit; production structure, which consists in determining the place, means and content of activities aimed at yielding prosperity; knowledge structure, which is based on the capacity to influence ideas and beliefs which are socially legitimate and sought-for and in controlling access to means of communication of the ideas and belief $\mathrm{s}^{10}$.

This latter notion of knowledge structure will impact that of soft power put forward by works carried out by Joseph Nye ${ }^{11}$. From then on, there is a new way of looking at vectors and forms of exercising power according to which power is no more exclusively related to military capabilities. Therefore, geographical and demographic criteria are put into perspective to the benefit of intangible resources such as technology, ideas and culture. Nye will coin the expression soft power, as opposed to hard power, the traditional exertion of

\footnotetext{
${ }^{8}$ Lukes, Power, 34 .

9 Susan Strange, States and Markets: An Introduction to International Political Economy, 2 ${ }^{\text {nd }}$ Ed. (London: Pinter 1994), 24-25.

${ }^{10}$ Strange, States and Markets, 26-30.

11 Joseph S. Nye, Bound to Lead: The Changing Nature of American Power (New York: Basic Books, 1991).
} 
power emanating from the use of classical means of coercion (military and economic). In other words, "a country may obtain the outcomes it wants in world politics because other countries - admiring its values, emulating its example, aspiring to its level of prosperity and openness - want to follow it."12 Joseph Nye's theory tries to show that both types of power coexist, but that the soft power is increasingly central in a world where the most powerful is not so much he who strikes more powerfully but he who demonstrate the capacity of gathering more actors around him, mastering the information, and determining the agenda.

In this study, the paradigm of structural power will be used in a bid to highlight aspects of our first hypothesis. This theoretical approach is advantageous in as much as it goes beyond the discrimination between hard power and soft power by allowing within the same framework classical parameters of power (military force, economic and financial weapons) and modalities for the use of soft power (persuasion, domination value and culture). Furthermore, this approach allows us to have access to international actors as well as non-state actors that, from many perspectives, can be considered as agents of a country's reputation, image, thus power.

\section{Does China challenge the structural power of France in the Francophone Africa?}

Statistics have revealed the extraordinary increase in the interaction between China and African countries during the last fifteen years. Commentators have generally emphasized on the commercial invasion, the unfettered energy frenzy, human rights and good governance. Even if some research have centered on the anthropologic point of view ${ }^{13}$, taking into account French-speaking African countries $^{14}$, no research has systematically been carried out on the impact of

${ }^{12}$ Joseph S. Nye, Soft Power. The Means to Success in World Politics (New York: Public Affairs, 2004), 5.

13 Antoine Kernen and Benoit Vuillet, "Small Chinese Merchants and Entrepreneurs in Mali and Senegal", The China Monitor 42 (2009): 4-6; Mathilde Dupré and Weijing Shi, "La présence chinoise en Afrique de l'Ouest: le cas du Mali et du Bénin," French Development Agency - AFD, Working paper 69 (2008).

14 François Lafargue, "La Chine: stratégies d'influence en Côte d'ivoire," Monde Chinois 8 (2006): 39-48; Vidhan Pathak, "China and Francophone Western Indian Ocean Region: Implication for Indian Interests," Journal of Defense Studies 3 (2009): 79-102. 
interactions between China and the so-called francophone countries until now. Early in 2005, authors suggested that France could hold back China's progress into Africa by identifying its interests and sharing the work with the United States of America ${ }^{15}$. An internal study carried out by the French Ministry of Foreign Affairs shows that Chinese's presence in Africa is essentially a danger for governance and democratization ${ }^{16}$. In the days ahead the China-Africa summit held in Beijing on November 2006, a few prescriptive analyses, with a dose of nostalgia, depicted the Chinese presence in Africa as a threat to France interests. Some wrote: "Good-bye "France-Africa", "Welcome China-Africa!"17

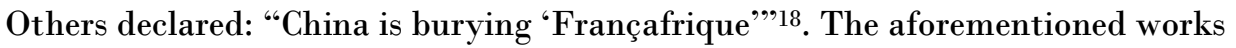
bring out some gaps considering the reality of China's weight on Frenchspeaking Africans countries. First, it can be observed that the commentators almost ignore the historical context between France and its former colonies and territories. In addition, the data seems to be only interested in evaluating power relationship on the material aspect between China and France, and enumerating resources that justify Chinese efficiency. Third, the influence of China in this region derived from the prescriptive method used by the authors. By so doing, they tend to perpetuate the tradition of prospective and prescriptive exercises through which geopolitics is considered as an ideological tool rather than a scientific subject ${ }^{19}$.

In order to go beyond this "declinist literature", we shall focus on structural power. This methodological choice should enable us to include both tangible and intangible elements of power. The structural approach seems pertinent given that France and China actions are carried out in a group of 'Weak states'. A weak state is a country "unable or unwilling to provide

${ }^{15}$ Antoine Glaser and Stephen Smith, Comment la France a perdu l'Afrique? (Paris: Calmann-Levy, 2005), 267.

16 Centre d'Analyse et de Prévision, "La Stratégie Africaine de la Chine," quoted in La Lettre du Continent, July 13, 2006.

17 Yves Lacoste, "La Chine change l" 'ordre' du monde," Hérodote 125 (2007), 3-6.

18 Serge Michel and Miche Beuret, La Chinafrique: Pékin à la conquête du continent noir (Paris: Grasset, 2008), 147-175. Other publications and French Television documentaries adopt a similar perspective, for example: Jean-Marc Gonin and Julien Nessi, "Le triomphe de Pékin," Le Figaro, November 04, 2006; Dominique Dhombres, "Les entrepreneurs chinois en Afrique," Le Monde, January 08, 2009; Serge Michel and Fabrice Monod, "Drapeau rouge sur le continent", France 5, January 06, 2009.

${ }^{19}$ Guillaume Devin, Sociologie des relations internationales (Paris: La Découverte, 2002), 28. 
essential public services, which include fostering equitable and sustainable economic growth, governing legitimately, ensuring physical security, and delivering basic services" ${ }^{20}$. Moreover, we suggest that the persistence of personal and unscrupulous business networks blurs further the comprehension of France's influence over French-speaking African countries.

\section{Assessing the Facets of French and Chinese influences}

\section{On the security structure}

From the security structure point of view, where power is generated from the provision of security, many elements of comparison seem to reveal the weakness of China in Francophone Africa. Apart from cooperation and a scarce military assistance, there is not any direct link between the People's Liberation Army (PAL) and its African counterpart of the francophone area. Nevertheless, the development of a military cooperation centered on mutual visits, sporadic training and bilateral medical exercises is on the rise. The 2007-2008 batch of international training of military telecommunications held in Xi'an, China with the participation of Officer from Gabon and Cameroon is an example ${ }^{21}$. Furthermore, sixty Chinese hospital attendants and medical doctors with their Gabonese fellows attended a "Humanitarian exercise and medical assistance between China and Gabon" called Ange de la Paix 200922. During the past years, the military support to countries which are the focus of our study is unquestionable; this can be illustrated, for example, by the donation of uniforms to the Cameroonian police in 2006, the donation of ambulances and the armored anti-mines to Senegal in $2007^{23}$.

However, France comes to occupy an honorable position according to many factors that deal with the security structure. In Francophone Africa, this

\footnotetext{
${ }^{20}$ Susan E. Rice and Steven Patrick, Index of State Weakness in the Developing World (Washington, D.C.: The Brooking Institution, 2008), 5.

${ }^{21}$ Personal communication with officers from Cameroon and Gabon who participated in the training in China, July 18, 2008.

22 "Arrivée au Gabon d'un groupe des médecins militaires chinois pour un exercice médical," People's Daily, June 18, 2009.

${ }^{23}$ Jonathan Holslag, "China's Next Security Strategy for Africa," Asia Papers 3 (2008), 6.
} 
is unquestionable. Actually, the agreements signed between France and African states in the domain of defense are no longer a matter of military union but a community of destiny rather. "This is because the military cooperation is connected with a certain harmonization of political life and somehow with the existence of common political institutions."24 In order to supervise this policy, France has designed an African framework for military cooperation revolving around the applications of agreements in military and technical support. Practically, this policy is based upon two notions: presence and intervention ${ }^{25}$. The list of these agreements should be associated with a permanent military force whose mission is to assist to intervention force and to facilitate the operations. Thanks to its status of colonial power, France has signed agreements with its colonies in the domain of defense. Considering the conclusion of these agreements, France has the right to intervene militarily whenever necessary. Most of these agreements (Accords de défense) have recently been renegotiated and, it is said that they explicitly forbid France from acting in case of local unrest. This direct link sometimes facilitates the presence of French military advisers. Ivory Coast is an example. In addition, regarding the staff, the French army still maintains several military bases in five African countries (950 soldiers in Ivory Coast, 900 in Gabon, 350 in Senegal, 100 in Chad, 230 in Central African Republic and 2900 in Djibouti) ${ }^{26}$. A sixth country has to be mentioned since in 2013, when the French ministry of foreign affairs announced the establishment of a station of 1000 soldiers who would permanently operate in $\mathrm{Mali}^{27}$. Consequently, France possesses an efficient force of projection in the area of central and western Africa. Asserting of the number of interventions carried out these last decades: 1964, in Gabon; 1968-1972, in Tibesti (Chad); 1977, in Zaire; 1977, in Mauritania; 1978, in Kolwezi (Zaire); 1978-1980, in Chad; 1979-1981, in Central African Republic; 1983; in Chad; 1985, in Chad (against Libya); 1986, in Togo; 1989, in the Comoros; 1990-1993, in Rwanda; 1993, in Zaire; 1994, in Rwanda; 1995, in the Comoros; 1998, in

\footnotetext{
${ }^{24}$ Maurice Ligot, "La coopération militaire dans les accords passés entre la France et les États africains et malgaches d'expression française," Revue Politique et juridique d'Outre-Mer (1963), 517.

${ }_{25}$ Patrice Bakong, La politique militaire africaine de la France (Paris: L'Harmattan, 2012), 42.

26 "Etat des lieux des bases militaires françaises en Afrique," L'Express, December 12, 2009.

27 "Mille soldats français resteront au Mali de "façon permanente"," France 24, April 6, 2013.
} 


\section{Olivier Mbabia}

Zaire; 2002, 2004 and 2011, in Ivory Coast; 2006 and 2008, in Chad; 2008, in Djibouti ${ }^{28}$. More recently, there were the ousting of presidents Laurent Gbagbo and Muammar Gadaffi, and the launching of two military intervention in 2013 (Operation Serval in Mali from January and Operation Sangaris in Central African Republic from December).

It should be noted finally that military equipment's sales and donations within the framework of technical cooperation on the one hand, and the systematic training of Africans junior and senior officers in both French and African schools on the other hand should not be forgotten. Suffice it to remember that two former officers trained in France are now head of states in Africa but also very close allies of Paris in the region, namely President Denis Sassou Nguesso in Congo and President Idriss Deby Itno in Chad.

\section{On the financial structure}

Like Susan Strange notices, the issue of financial structure is considered as the capacity of offering, refusing, or asking for some credits, it is also related to the currency. The Chinese financial structure as opposed to the French one in Francophone Africa seems to be limited. Our emphasis will be laid on the ability of issuing credits given that the target states are economically deprived. In reality, thanks to its budgetary reserved funds, the Chinese government allocated important credits to African countries: 5 billion dollars of preferential loans on the setting up of a Development Fund of the same value; the abolition of heavily indebted and poor countries' debts; 10 billion dollars of preferential loans, of which 1 billion should enable African small and medium size companies to take off, 20 billion lending for development assistance ${ }^{29}$. These important credits, that will contribute somehow to the enhancement of Chinese investment and the development of many African sectors (infrastructures, industrial, agricultural and entrepreneurial) are however short-term measures.

${ }^{28}$ See Raphael Granvaud, Que fait l'armée française en Afrique (Marseille: Agone, 2009).

29 French-speaking African countries present a situation of economic vulnerability and poor socioeconomic development records. In fact, 15 of the selected countries fall among the United Nations category of Least Developed Countries (LDC), of which 10 over 14 countries of the Franc Zone: Benin, Burkina Faso, Central African Republic, Chad, Equatorial Guinea, Guinea Bissau, Mali, Niger, Senegal and Togo. Five countries are not members of the Zone: Comoros, Djibouti, Guinea, Madagascar and Mauritania. 
The real transformation lies on the fact that these credits do not respect the traditional framework imposed by international financial institutions. The vulnerable economies of Francophone Africa countries have always been managed by, and largely depend on, different policies implemented by the World Bank and the International Monetary Fund.

Financially, France enjoys a noble position in relation to the countries that make up Francophone Africa. The two aspects of its financial power are illustrated by the control over the currency used in the Franc Zone and the dominance of France on the banking system of this group of countries. Firstly, since the colonial period, France has been managing the currency of its colonies known as "franc des colonies d'Afrique-CFA" (Franc of African colonies) which has become "franc de la communauté financière d'Afrique". After the independences, the 14 countries of the Franc Zone, of which eight are part of the West Africa Economic and Monetary Union (UEMOA - Benin, Burkina Faso, Ivory Coast, Guinea Bissau, Mali, Niger, Senegal and Togo) and six part of the Central Africa Economic and Monetary Community (CEMAC Cameroon, Gabon, Congo, Central African Republic, Chad and Equatorial Guinea), are obliged to deposit their foreign exchange reserves to the French Public Treasury. This currency, whose convertibility was guaranteed to the French Franc from 1945 to 1999 and to the Euro afterwards, is designed and printed by the Bank of France in Chamalières, a small locality in south-central France.

The shares of trade between France and the countries of the Zone are higher than those with other African regions: above 50 per cent of the national trade in many countries ${ }^{30}$. The reality is that both the Central Bank of West Africa States (BCAO) and the Central Bank of Central African States (BEAC) have monetary policies dictated directly by France and, to some extent, by other countries of the Euro zone. This confirms the weaknesses and the 'servitude' of a group of countries which are unable to independently define their economic and social policies. ${ }^{31}$ Secondly, the domination of French banks

${ }^{30}$ Demba Moussa Dembele, "Mauvais comptes du franc CFA," Le Monde Diplomatique, June 2004.

31 Tchundjang Pouemi, Monnaie, servitude et liberté: La répression monétaire de l'Afrique (Paris: Éditions Jeune Afrique, 1980); Demba Moussa Dembele, "Le franc CFA en sursis," Le Monde diplomatique, July 2010. 


\section{Olivier Mbabia}

over the concerned countries ought to be underlined. A picture of the major banks operating in Francophone Africa and in the Franc Zone indicates the omnipresence of French banking institutions in this geographic area. In this respect, Roland Marchal observes: "The major French banks (Banque Nationale de Paris, Société Générale and Crédit Lyonnais) represent 70 per cent of banking sector activity in the Franc Zone. ${ }^{32 "}$

\section{On the production structure (economy)}

The existence of a vital economy has often been considered as one of the key conditions for a country to be considered a powerful one. The term 'economic weapon' is generally used to denote the use of economic interactions by a state for foreign policy goals ${ }^{33}$. Though, the recent evolution has more or less included actors who claim important positions in terms of authority and exportation of goods besides the state entity. This development leads some scholars to conceive power as: "the ability of a person or a group to influence the results in such a way that their preference should come before others'." 34 If many operators invest different domains of power (namely NGO, legal entities, diaspora, etc.), multinational enterprises are with no doubt those that have mainly focused their attention on the field of economic power ${ }^{35}$. However, these non-state actors do not aim at being an alternative to the State because "resisting, attacking, distorting, combining with, influencing the State is in itself a source of authority, an attribute and expression of power. ${ }^{36 "}$

Within the structure, concerned with activities related to the mobilisation of wealth and prosperity, Chinese companies in Francophone Africa, State-owned enterprises or not, permit to develop successful trade

${ }^{32}$ Roland Marchal, "French Perspectives on the New Sino-African Relations," in China Returns to Africa, eds. Chris Alden, Daniel Large, and Ricardo Soares de Oliveira (London: Hurst \& Company, 2008), 181-196.

33 Marie-Hélène Labbé, L'Arme Économique dans les Relations Internationales (Paris: Presses Universitaires de France, 1994), 3.

${ }^{34}$ Susan Strange, The Retreat of the State: The Diffusion of Power in the World Economy (Cambridge: Cambridge University Press, 1996), 35.

35 On the concept of "Power diffusion", see Joseph S. Nye, The Future of Power (New York: Public Affairs, 2011).

${ }_{36}$ Pierre Buhler, La puissance au XXIe siècle. Les nouvelles définitions du monde (Paris: CNRS, 2011), 284. 
opportunities. Moreover, it is worth mentioning that the Chinese industrial strength attracts many traders and African entrepreneurs, especially Francophone living in China. The latter is thus considered as a place where it is possible to create wealth ${ }^{37}$. Here, the private facet of power allows Chinese, to some extent China, to have a considerable advantage with regard to the role played not only by its commercial diaspora but also its qualified workers. Whereas the former contributed to the booming commercial interactions between China and Africa, the latter participated in numerous infrastructural achievements (bridges, dams, hospitals, factories, sport complexes, roads, etc.). Most of the time, Chinese know-how was needed where local manpower couldn't implement some specific tasks ${ }^{38}$. In fact, this resulted in the extraordinary rise of trade between China and Africa countries in general, from 10 billion dollars in 2000 to more than 198 billion dollars in 2012, according to Chinese statistics. ${ }^{39}$ Among China's major African partners (Angola, South Africa, Sudan, Nigeria and Egypt), there is no country of the francophone region. However, we find Congo ( $5^{\text {th }}$ in 2011) among the major African exporters to China. The latter has indeed surpassed France and the U.S. to become the first commercial partner of the continent. But, when examining the details of this trade relationship, one can observe two facts: it remains modest in Francophone Africa, and the trade value still appears relatively weak compare to the trade interactions between these countries and France. Let consider some statistics of the volume of trade between China and CEMAC countries in 2010: 763.3 million Euro exchanges with Cameroon, 37.1 million with Central African Republic, 2479.6 million with Congo, 841.3 with Gabon, 798.3 million with Equatorial Guinea and 616.4 million with Chad ${ }^{40}$.

Within the Franc Zone, France continues to absorb 25 per cent of countries exports and, thanks to these countries, it realizes a trade surplus with

${ }^{37}$ During my investigations in China I discussed with people (students and entrepreneurs) from Mali, Senegal, Congo Republic of, Guinea and Cameroon living in Shanghai, Guangzhou, Shenzhen and Hong Kong, April-May 2009.

${ }^{38}$ On a construction site in Yaoundé (Cameroon), the Shaanxi Engineering Construction Group Co. had to call 40 boilermakers from China because local craftsmen were unable to professionally accomplish their contract. Interviews in Yaoundé, August, 2008.

${ }^{39}$ China-Africa Economic and Trade Cooperation, prepared by the Information Office of the State Council of The People's Republic of China (Beijing, 2013).

${ }^{40}$ These data and statistics are provided by the European Commission, http://ec.europa.eu/trade/. 


\section{Olivier Mbabia}

Africa $^{41}$. In fact, France commercial balance with Franc Zone countries is highly comfortable. Back to CEMAC countries, in 2011, France has benefited a trade surplus of 710 million euro (see Table 1). If we look at the most dynamic Francophone economies of West Africa, France enjoys a trade surplus of 802.3 million euro with Benin, the first surplus of the Zone and the second on the continental scale ${ }^{42}$. Moreover, while the trade between France and Ivory Coast accounted for 1434 million euro and 794 million euro for Senegal in 2010, China on its side scored 170.7 million with Ivory Coast and 412.2 million with Senegal. In the field, French major firms still occupy prosperous positions: Total, Perenco, Areva, Eramet, Technip in mines and petroleum sectors; Rougier, Thébault Transbois in forest exploitation; Véolia, Vinci, Bouygues, Lafarge, Razel, Dumez, Gaz de France in infrastructure and water supply; and Orange and Alcatel in the sector of telecommunications.

Table 1: France-CEMAC trade statistics (€ millions)

\begin{tabular}{lllllll}
\hline & Cameroon & CAR & Congo & Gabon & Eq. & Chad \\
& & & & & \multicolumn{3}{c}{ Guinea } & \\
Exports & 632 & 43.3 & 488 & 779.6 & 194.7 & 104.4 \\
Imports & 290.4 & 8.6 & 527.7 & 114.7 & 431.7 & 158 \\
Total & $\mathbf{9 2 2 . 4}$ & $\mathbf{5 1 . 9}$ & $\mathbf{1 0 1 5 . 7}$ & $\mathbf{8 9 4 . 3}$ & $\mathbf{6 2 6 . 4}$ & $\mathbf{2 6 2 . 4}$ \\
Balance & 341.5 & 34.6 & -39.7 & 664.8 & -237 & $\mathbf{- 5 3 . 6}$ \\
\hline
\end{tabular}

Source: Regional Economic Service, Embassy of France in Cameroon, February 2012.

Besides merchandise trade, France economical implantation reaps huge benefits from services industry. A particularly significant example is Air France (the French flag carrier) destinations and frequencies to the African continent. Air France possesses a 75 years' presence in Africa, and rounds cities of Francophone countries with 75 flights per week $^{43}$. To date, no Chinese airline

${ }^{41}$ Marchal, "French Perspectives".

42 Direction Générale du Trésor, “Commerce bilatéral franco-béninois en 2011," February 24, 2012.

4310 weekly flights to Douala and Yaoundé; 9 to Brazzaville and Pointe-Noire; 7 to Abidjan, Bamako, Dakar, Libreville and Ouagadougou; 5 to Cotonou; 4 to Lomé and Niamey; 3 to Malabo, N'Djamena, 
company flies to these countries. Hence, Air France has recently created Air CEMAC, the future central African air carrier, strategic company. As partner with the majority of shares (34 per cent) of this sub-regional company it will ensure the choice of aircrafts, define the strategy, launch flights, select and train crewmembers.

If French enterprises have launched the diversification of their markets with the establishment of privileged partnership with countries like Nigeria, South Africa, Angola and Mozambique, they are still well represented in Francophone Africa. These markets remain their cornerstone from which they move to other business destinations over the continent. For instance, the Bolloré Group, which is deeply established in virtually every strategic domain (railways, seaports and logistics) in the Franc Zone, has reinforced its roots in Southern Africa and is now on its way to Eastern Africa via Ethiopia. Incidentally, this evolution weakens trade relationship with Francophone Africa countries. This can be illustrated with the case of Ivory Coast: France's first partner in the Franc Zone, it occupies the $4^{\text {th }}$ rank among France's subSaharan partners in 2010 and the $5^{\text {th }}$ rank in terms of market shares, scoring only 4.6 per cent, behind Nigeria (36 per cent), Ghana (11 per cent), Angola (11 per cent), and South Africa (8 per cent) ${ }^{44}$.

\section{On the knowledge structure}

One of the key instruments that permit to set influence abroad is the knowledge structure, which is conceptually close to Lukes' three-dimensional view of power as well as Nye's soft power. The knowledge structure "comprehends what is believed (and the moral conclusions and principles derived from those beliefs); what is known and perceived as understood; and the channels by which beliefs, ideas and knowledge are communicated - including some people and excluding others." 45 It has been recently argued that Chinese strategic influence centers on seduction in order to attract leaders, elite and young Africans. Focusing on the notion of soft power, authors have generally

Nouakchott and Bangui. In addition, the carrier makes three flights to Antananarivo and seven to Conakry per week.

${ }^{44}$ Ambassade de France en Côte d'Ivoire, "L'économie ivorienne en fiches," March 2011.

${ }^{45}$ Strange, States and Markets, 119. 
enumerated initiatives like cultural promotion, teaching mandarin, Chinese media offensive. In fact, Chinese leaders have shown a great will to influence ideas in Africa through several methods. First of all, comes the promotion of Chinese language and culture: up to 20 Confucius Institutes have open doors to Africa since the first inaugurated in 2005 in Kenya. In 2006, 3737 African students register in Chinese universities, as to 2757 in 2005, an increase of 40 per cent $^{46}$. The number is increasing constantly due to the multiplication of scholarship offered by Chinese government (5500 scholarship pledged in 2009). As a recall, French campuses had in 2005-2006 registered 103235 African students. In the media domain, which is another means of attracting and influencing people, China is not less active. The China Central Television (CCTV) has launched in September 2007 a channel broadcasting in French language for Francophone viewers. As far as the live news channel in English is concerned, CNC World, launched by Xinhua News agency in July 201047, is having auditors in Africa over Anglophone countries.

It is however important not to mistake presence for influence. Today, there are only five Confucius Institutes in Francophone Africa (Cameroon, Benin, Madagascar, Mali and Togo). In addition, no Chinese-promoted radio station or television could pretend cover the francophone area. Moreover, when compared to the number of African students trained in France, the number of students in China is still very low. Since the colonial period, the former displays a strong set of cultural, educational, normative and media institutions to which every former colony pay tribute. It is worth reminding that the power of language imposed during the colonial era is the plinth of that influence.

The first vector concerns the institutionalization of school systems entirely based on the French model. Surprisingly, this pattern is still implemented in the majority of Francophone countries, with few changes. In these countries, there is a vast network of agencies for the teaching of French abroad funded by the French ministry of education. Since these schools welcome local students (from the host and neighboring countries), they do not

\footnotetext{
46 "Les universités chinoises attirent davantage d'étudiants africains," Beijing Review, December 18, 2007.

${ }^{47}$ "China Puts Best Face Forwards with News Channel," The New York Times, July 1, 2010.
} 
only show France cultural merits abroad, but they found multiple affinities with them in the long term. Thus, always based on the sharing of language, Hachette International is the leading (a monopoly) school textbooks publisher in Francophone Africa. Hachette possesses 85 per cent of market shares in school textbooks publishing in those countries via Edicef and Hatier International ${ }^{48}$. As a result, the governments of Francophone African countries do not have any control over the content of this activity: about 80 per cent of the books used by African school students in their country are printed abroad.

The higher education system constitutes the other major components of the mechanism of intellectual influence. In spite of the previous application of drastic consular decisions, the number of African students on French campus is fairly large. During the year 2010-2011 for example, one-third of foreign students in France were Africans. Paradoxically, this number of 100000 increased from 91728 students in 2008, of which 38,714 are Francophone ${ }^{49}$. In addition, France trains large numbers of Francophone leaders and bureaucrats especially in the 'prestigious' École nationale d'administration (ENA). The consequence of this intellectual influence is that the weight of this country within key institutions of Francophone countries is tangible. The Organization for the Harmonization of Business Law in Africa (OHADA) is a good example ${ }^{50}$. If this framework aims at resolving juridical issues within the state members through the unification of business laws, it contributes, even indirectly, to valorize the French law.

Another tool is the cultural diplomacy whose major vectors are the cultural exchange institutions and media. The main objective of this diplomacy is not only to sell cultural works but also to change the way other people perceive $u^{51}$. French cultural centres are likely means of France cultural diplomacy in the world, especially in Africa. Media play an instrumental role on

48 "La France règne en maître sur le marché des manuels scolaires en Afrique francophone," Le Monde, June 10, 2010.

${ }^{49}$ France enrolled 284659 international students. Other main destinations for African students are South Africa (43000 students), United States (34000 students) and United Kingdom (33000 students). See "La France attire-t-elle les étudiants africains," Slate Afrique, May 27, 2012; "La mobilité des étudiants du Maghreb et d'Afrique subsaharienne," Les notes de Campus France 7, October 2009.

${ }^{50}$ The OHADA is composed of 14 countries of the Franc Zone plus Comoros, Guinea and the DRC.

51 Robert Frank, "Diplomatie et transferts culturels au XXe siècle," Relations Internationales 1 (2003): 319-323. 
this regard. Just considering the sharing of French language, one can notice that the French Radio and Television Channels broadcasting abroad have their largest public essentially in Francophone Africa. For this reason, the media of the "Audiovisuel exterieur de la France", namely Radio France internationale (RFI), TV5 and France 24 mark a natural echo in this region ${ }^{52}$. Given to the fact that the vocation of these media is to "break the news with a French vision and to convey French values and perspectives throughout the world", we can consider them as vectors of influence in the hands of their country. This is especially true for RFI. The station was launched in 1931 as 'Poste colonial' (colonial station), today it scores 33.1 million African listeners out of an audience of 45.5 million; 24.5 million of which live in Francophone African countries.

Finally, on the discursive dimension, the device that France cultural diplomacy tends to emphasize is the fact that Francophone Africa can flourish sustainably only in consubstantial relationship with a protector, a kind of hegemon. This process is close to the art of persuasive power (Lukes) whose purpose is to

\begin{abstract}
“(...) prevent people, to whatever degree, from having grievances by shaping their perceptions, cognitions and preferences in such a way that they accept their role in the existing order of things, either because they can see or imagine no alternative to it, or because they see it as natural and unchangeable, or because they value it as divinely ordained and beneficial. ${ }^{3}$ "
\end{abstract}

To put this another way, in a context of asymmetric relationship, the dominated countries in Francophone Africa accept their domination, either by resignation or by accepting its foundations. This process of legitimation, that passes through a control of the media or the socialization processes which aims

${ }^{52}$ Refer to "L'Audiovisuel extérieur de la France": http://www.aefmonde.com/.

${ }^{53}$ Lukes, Power, 24. 
at conquering the hearts and minds, is called 'cultural imprinting' by Edgar Morin. It is considered by Steven Lukes as 'indoctrination' ${ }^{54}$

In this case, the elite (rulers or not) and even some people of these areas, show a particular interest in the French model. We should bear in mind that manipulation strategies exist. Many examples illustrate this trend. The weekly meetings of Ministers in several countries stand on Wednesday morning as in Paris (Benin, Gabon, Ivory Coast, Mali, and Togo). In retrospect, at the end of a visit to France on April 3, 1991, the Cameroonian President Paul Biya congratulated himself to the reporters: "I am among the best students of François Mitterrand!" 55 These common identities denote the significance of the symbolic dimension of the French influence in the region. Following Bourdieu's perspective, the so-called symbolic power is invisible and is mainly carried out by cognitive structures. In other words, it is supplied by the approval of those who bear it because they consider the ruling order legitimate.

\section{China in Francophone Africa: short-term event or systemic shift?}

The presence and power of China in Africa is certainly growing, but since it is the Francophone Africa the region at stake, it is important to determine the limits to this phenomenon. As for the place that China actually occupies under the four facets of power as elaborated above, several indicators tend to confirm the Chinese lateness in some cases.

According to Frederic Charillon, one the myths of the debate on France foreign policy is that the decline is prominent.

\footnotetext{
Often unscientific, this observation of decline may be related to three different perceptions: encrypted declining of France representation in the world, less quantifiable decline in political influence, the decline of the French desire to play a global role and assume a global power position ${ }^{56}$.
}

54 Traité de relations internationales, ed. Gérard Dussouny, vol. 2, Les théories de l'interétatique (Paris: L'Harmattan, 2008), 81.

55 Mongo Beti, La France contre l'Afrique (1993; repr. Paris: La Découverte, 2006), 158.

${ }^{56}$ Frédéric Charillon, La France peut-elle encore agir sur le monde? (Paris: Armand Colin, 2010), p. 46. 
Along the same line, the decline of France in Africa as argued by some commentators with a hint of nostalgia or disappointment may be the result of the success of China ${ }^{57}$.

With regard to security structure, it is not enough to say that the Chinese defense budget (106.4 billion dollars in 2012) is higher than that of France (around 39.52 billion dollars in 2012) or to consider the number of soldiers serving in peacekeeping operations in Africa to conclude that France is in difficulty. It is worthy to note that France is the first to be called for help by Francophone African countries in case of serious security crisis. In reality, France has always been known as the "Gendarme of Africa" conferring it international legitimacy and room for manoeuvre in Francophone Africa. Military operations in Côte d' Ivoire (2011), Mali and Central African Republic (2013-ongoing) perfectly illustrate this state of affairs. Moreover, the legitimacy of France in these interventions is not challenged by allies of the Treaty Organization (NATO) and the European Union, which actually give political and logistic supports. Even China gave its support to France on the intervention in $\mathrm{Mali}^{58}$. It is due to this local, regional, international and also moral legitimation that France prevails over China.

Concerning the knowledge structure and that of finance, it is observed that initiatives supported by the Chinese government are so far limited. The French influence in these areas is immeasurable and can be perceived both qualitatively and quantitatively through declarations, customs, behavior and also artistic production of Francophone Africans.

In reality, the production structure (economy) seems to be the most disputed and the one in which Beijing is likely to assert its competitiveness. In this light, we notice more generally a shift of the center of gravity towards Asia, China in particular. However, China and India are not alone. Other dynamic emerging economies are present too, such as Brazil, Turkey, South Korea and Malaysia. Due to the diffusion of power beyond the State in the production structure, it is neither France nor its Francophone African allies that determine

${ }^{57}$ See Michel and Beuret, La Chinafrique.

58 Zhang Chuanjie and Jean-Pierre Dozon, "Public Perception of China in Francophone Africa," Carnegie-Tsinghua Center for Global Policy, April 03, 2013. 
the place of production of wealth and prosperity. This role is played by other actors of the regional and international political economy. For example, the people look East. Therefore, lays the Chinese strength or asset on its competitiveness. Still, the former colonial power resists holding significant interests in oil and mining, as well as niche markets with the help of mechanisms and unscrupulous business networks closely related to the French State.

\section{Limits of French power in Francophone Africa}

While firmly rooted in the African Francophone zone, the influence of France in the region still seems to face three important challenges pertaining to French's leadership conception of power. The first challenge relates to a loss of direction, that is to say the upheaval of the original context and methods of interaction with partner countries. Outrageous personalization of relations between French leaders and their African counterparts played such interference. Admittedly, the end of the Mitterrand administration ushered in this turbulent era with the disappearance of a privileged partner like Houphouët Boigny of Ivory Coast, and later that of veteran presidents Gnassingbé Eyadema of Togo and Omar Bongo of Gabon, who seem to have surprised France. Personal and secret diplomacy, and the propensity for business intermediaries, with parallel networks (Freemasonry, mercenaries or secrets advisors), caused the dismissal of the Secretaries of State for Cooperation who were asked to leave their function, because they were considered too much reformist by Paris and also by some African presidents (Jean-Pierre Cot in 1982 and Jean-Marie Bockel in 2008). Today, despite official and public declarations, businessmen networks and political friendships remain important and bound to practices and anterior networks. ${ }^{9}$ Indeed, as noted by Christopher Clapham: "What distinguished relations between Africans leaders and France - in sharp contrast to those with

59 Antoine Glaser and Stephen Smith, Ces messieurs Afrique: Le Paris-village du continent noir (Paris: Calmann-Lévy, 1992); Antoine Glaser and Stephen Smith, Ces messieurs Afrique : Des réseaux aux lobbies (Paris: Calmann-Lévy, 1997); François-Xavier Verschave, La Françafrique: Le plus long scandale de la République (Paris: Stock, 1998); Daniel Bourmaud, "Discours de rupture et politique d'impuissance: La politique africaine de Nicolas Sarkozy," in Les politiques publiques sous Sarkozy, eds. J. de Maillard and Y. Surel (Paris: Presses de Sciences Po, 2012), 167-188. 
Britain, the United States, or the former Soviet Union - was the way in which they were incorporated into a network which was intimate in character but international in scope. It provided a means of conducting diplomacy which sometimes more closely resembled the world of domestic politics than that of formal inter-state relations." 60

The second limit appears to be the emergence of competition. Contrary to what is said and written in the media, this competition mainly comes from "allies" and friendly countries like the United States. Actually, France seems now to be losing control to the benefit of the United States. Thus, the FrancoAmerican rivalry explains, to some extent, the relative decline of French influence. In commercial terms, the value of trade between the United States and the countries of the CEMAC in 2010 shows that the US topped not only China but also the 27 European Union countries (including France). And has as important commercial partners there: Congo (2 544.2 million euro), Gabon (1 751.8 million euro), Equatorial Guinea (1 798 million euro) and Chad (1 516.7 million euro). Only Cameroon (329.7 million euro in 2010) and CAR (12.5 million euro) are exceptions. The US position is also visible through a military cohabitation with France in Djibouti, with an increased influence in the Great Lakes region previously dominated by France. In the cultural field, young Francophone elite prefer the American way and are attracted by North America. As a matter of fact, large numbers of Francophone Africans trained in France or Belgium are moving to the US or Canada (Quebec). As Achille Mbembe puts it, "More fundamentally, France is losing a large part of the cultural influence it once had on African elite. (...) The United States is clearly the principal beneficiary of this defection." 61 Exit therefore the sustainability of the de facto arrangement that promoted France as the exclusive guardian of Francophone Africa during the Cold War.

The emergence of "the rest of the world" is a second aspect of this competition. In other words, it is not France which is falling or is being superseded in Francophone Africa but the fact is that the rest of the world

${ }^{60}$ Christopher Clapham, Africa in the International System: The Politics of State Survival (Cambridge: Cambridge University Press, 1996), 89.

${ }^{61}$ Achille Mbembe, Sortir de la grande nuit (Paris: La Découverte, 2010), 98. 
suddenly evolves and races for opportunities in that region (Persian Gulf countries, Turkey, Japan, South Korea, Taiwan, Malaysia, Indonesia, India, Brazil and China). Incidentally, it creates widespread competition between different extra-continental actors increasing ipso facto options for Africans. In addition, there is parallel since the late 1990 s to the reappearance of a SouthSouth perspective that seems fundamentally redefining the current international system. The restoration of this dynamic relationship between southern countries is the result of a growing economic power of emerging countries. ${ }^{62}$

Last but not least, the third limit is the difficulty for the French leadership to make an aggiornamento of their foreign policy style toward Francophone Africa. France seems to continue to confine its action towards the political elite when others put more emphasis on the battle to conquer the "hearts and minds". Limiting itself to these happy few, France paradoxically acts the same wrong way as China does. There is a challenge to adapt, in the sense of resizing its foreign policy tools in order to address the most relevant targets. In a multi-centric Francophone African environment, it is necessary to find the appropriate method for the situation. That is to say, to devise a strategy based on intangible resources of power that affect people, civil societies, the private sector, not one whose unique objective is to rescue corrupt and illegitimate governing elite.

\section{Conclusion}

That China disrupts established equilibrium in Francophone Africa seems undeniable and that such an upheaval allows it to claim a rule is less certain. This is demonstrated in this essay, considering its influence compared to that of the former colonial power, according to the four dimensions of structural power. Donor and emerging market, China is considered as a serious contender in the power of France in Francophone Africa. China also promotes through the

${ }^{62}$ See Alice H. Amsden, The Rise of "the Rest": Challenges to the West from Late industrializing Economies (Oxford: Oxford University Press, 2001). 
Forum of China-Africa Cooperation (FOCAC) unprecedented form of socialization and norms production for these countries. Without neglecting or underestimating the importance of Chinese involvement in Francophone Africa, the light has been shed on how multidimensional presence does not necessarily mean influence. However, it should be noted that the Chinese influence, so smaller it may be, could devote the decline or at least emphasize the relative decline of France in Francophone Africa.

Despite the positive image of China in Africa in general and in Francophone Africa in particular, the 'structural power' of the former colonial metropole remains substantial.

So shall France not be considered as a deus ex machina that would control everything in his former African possessions. Its influence there is also facing several challenges: difficulty to overcome the personal modes of interaction with these countries; the economic and cultural competition of the United States as well as those of emerging countries; the lack of flexibility that hinders a diplomatic shift towards intangible resources of power. Nevertheless, these recent developments seem to have affected only relatively the power of France, which continues to structure the overall coercive, economic, financial, cognitive and cultural environment in which Francophone African countries operate. As for France knowledge power, Jean-Pierre Cabestan, head of government and international studies at Hong Kong Baptist University, points out: "French soft power is bigger than China in francophone countries in Africa. France's relation with French-speaking African countries like Senegal is intimate. China is trying to make inroads in French-speaking countries in Africa, but it's hard for China." 63 In the political realm, there seem to be no concern either. Asked whether France can compete with China, the French Minister of Economy, Finance and Foreign Trade confidently replied: "France is still the second largest exporter to Sub-Saharan Africa behind China but ahead of the United States and Germany. We are also the fourth largest

${ }^{63}$ Toh Han Shih, “Experts Differ on China's 'Soft Power' in Africa," South China Morning Post, July 22, 2013. 
importer after the United States, China and Italy. (...) I do not want to criticize China, I find it obsolete. (...) We are not afraid of the Chinese." 64

64 "Pierre Moscovici: En Afrique, la Chine ne nous fait pas peur," interview by Julien Clémençot and Stéphane Ballong, Jeune Afrique, October 04, 2012. 


\section{Olivier Mbabia}

\section{REFERENCES}

Amsden, Alice H. The Rise of 'the Rest': Challenges to the West from Late industrializing Economies. Oxford: Oxford University Press, 2001.

Aron, Raymond. Paix et guerre entre les nations. Paris: Calman-Lévy, 1962.

Bachrach, Peter, and Morton S. Baratz. "The Two Faces of Power." American Political Science Review, no. 56 (1962).

Bakong, Patrice. La politique militaire africaine de la France. Paris: L'Harmattan, 2012.

Beijing Review. "Les universités chinoises attirent davantage d'étudiants africains." December 18, 2007.

Beti, Mongo. La France contre l'Afrique. Paris: La Découverte, 2006.

Bourmaud, Daniel. "Discours de rupture et politique d'impuissance: La politique africaine de Nicolas Sarkozy." In Les politiques publiques sous Sarkozy, edited by J. de Maillard e Y. Surel, 167-188. Paris: Presses de Sciences Po, 2012.

Buhler, Pierre. La puissance au XXI siècle: Les nouvelles définitions du monde. Paris: CNRS Editions, 2011.

Charillon, Frédéric. La France peut-elle encore agir sur le monde? Paris: Armand Colin, 2010.

Chuanjie, Zhang, and Jean-Pierre Dozon. "Public Perception of China in Francophone Africa." Carnegie-Tsinghua Center for Global Policy, April 03, 2013.

Clapham, Christopher. Africa in the International System: The Politics of State Survival. Cambridge: Cambridge University Press, 1996.

Dembele, Demba Moussa. "Le franc CFA en sursis." Le Monde Diplomatique, July 2010.

Dembele, Demba Moussa. "Mauvais comptes du franc CFA." Le Monde Diplomatique, June 2004.

Devin, Guillaume. Sociologie des Relations Internationales. Paris: La Découverte, 2002.

Dhombres, Dominique. "Les entrepreneurs chinois en Afrique." Le Monde, January 08, 2009.

Direction Générale du Trésor. "Commerce bilatéral franco-béninois en 2011." February 24, 2012. 
Dupré, Mathilde, and Weijing Shi. "La présence chinoise en Afrique de l'Ouest: le cas du Mali et du Bénin." French Development Agency Working Paper, no. 69 (2008).

Dussouny, Gérard, ed. Traité de relations internationales, vol. 2, Les théories de l'interétatique Paris: L'Harmattan, 2008.

France 24. "Mille soldats français resteront au Mali de "façon permanente'." April 6, 2013.

Frank, Robert. "Diplomatie et transferts culturels au XXe siècle," Relations Internationales no. 1 (2003): 319-323

Gilpin, Robert. The Political Economy of International Relations. Princeton: Princeton University Press, 1987.

Glaser, Antoine, and Stephen Smith. Ces messieurs Afrique: Le Paris-village du continent noir. Paris: Calmann-Lévy, 1992.

Glaser, Antoine, and Stephen Smith. Ces messieurs Afrique: Des réseaux aux lobbies. Paris: Calmann-Lévy, 1997.

Glaser, Antoine, and Stephen Smith. Comment la France a perdu l'Afrique? Paris: Calmann-Levy, 2005.

Gonin, Jean-Marc, and Julien Nessi. "Le Trioumphe de Pékin." Le Figaro, November 03, 2006.

Granvaud, Raphael. Que fait l'armée française en Afrique. Marseille: Agone, 2009.

Holslag, Jonathan. "China's Next Security Strategy for Africa." Asia Papers no. 3 (2008), 6 .

Kernen, Antoine, and Benoit Vuillet. "Small Chinese Merchants and Entrepreneurs in Mali and Senegal." The China Monitor no. 42 (July 2009): 4-6.

La Lettre du Continent, no. 498. July 13, 2006.

Labbé, Marie-Hélène. L'Arme Économique dans les Relations Internationales Paris: Presses Universitaires de France, 1994.

Lacoste, Yves. "La Chine change l'ordre du monde." Hérodote, no. 125 (2007).

Lafargue, François. "La Chine: stratégies d'influence en Côte d'Ivoire." Monde Chinois, no. 8 (2006): 39-48.

Le Monde. "La France règne en maître sur le marché des manuels scolaires en Afrique francophone." June 10, 2010. 


\section{Olivier Mbabia}

L'Express. "Etat des lieux des bases militaires françaises en Afrique." December $12,2009$.

Les Notes de Campus France. "La mobilité des étudiants du Maghreb et d'Afrique subsaharienne." No. 7, October 2009.

Ligot, Maurice. "La coopération militaire dans les accords passés entre la France et les États africains et malgaches d'expression française." Revue Politique et juridique d'Outre-Mer (1963).

Lukes, Steven. Power: A radical View. London: Macmillan, 1974.

Marchal, Roland. "French Perspectives on the New Sino-African Relations." In China Returns to Africa: a Rising Power and a Continent Embrace, edited by Chris Alden, Daniel Large, and Ricardo Soares de Oliveira, 181-196. London: Hurst \& Company, 2008.

Mbembe, Achille. Sortir de la grande nuit. Paris: La Découverte, 2010.

Michel, Serge, and Miche Beuret. La Chinafrique: Pékin à la conquête du continent noir. Paris: Grasset, 2008.

Michel, Serge, and Fabrice Monod. "Drapeau Rouge sur le Continent." France 5 Documentary. January 06, 2009.

Moscovici, Pierre. "Pierre Moscovici: En Afrique, la Chine ne nous fait pas peur." By Julien Clémençot and Stéphane Ballong, Jeune Afrique, October 04, 2012.

Nye, Joseph S. Bound to Lead: The Changing Nature of American Power. New York: Basic Books, 1991.

Nye, Joseph S. Soft Power. The Means to Success in World Politics. New York: Public Affairs, 2004.

Nye, Joseph S. The Future of Power. New York: Public Affairs, 2011.

Pathak, Vidhan. "China and Francophone Western Indian Ocean Region: Implication for Indian Interests." Journal of Defense Studies, no. 3 (2009): 79-102.

People’s Daily. “Arrivée au Gabon d'un groupe des médecins militaires chinois pour un exercice médical," June 18, 2009.

Pouemi, Tchunjang. Monnaie, servitude et liberté: La répression monétaire de l'Afrique. Paris: Éditions Jeune Afrique, 1980.

Rice, Susan E., and Steven Patrick. Index of State Weakness in the Developing World. Washington, D.C.: The Brooking Institution, 2008. 
Shih, Toh Han. "Experts Differ on China's 'Soft Power' in Africa." South China Morning Post, July 22, 2013.

Slate Afrique. "La France attire-t-elle les étudiants africains." May 27, 2012.

Strange, Susan. States and Markets. An Introduction to International Political Economy. 2nd ed. London: Pinter, 1994.

Strange, Susan. The Retreat of State: The Diffusion of Power in the World Economy. Cambridge: Cambridge University Press, 1996.

The New York Times. "China Puts Best Face Forwards with News Channel." July $01,2010$.

Valdmanis, Richard, and Andrew Osborn. "CAR President Urges U.S., France to Help Fight Rebels." Reuters, December 27, 2012.

Verschave, François-Xavier. La Françafrique: Le plus long scandale de la République. Paris: Stock, 1998. 


\section{ABSTRACT}

This article seeks to explain the determinants of France influence compared to that of China in Francophone Africa. Focusing on the paradigm of structural power as theorized by Susan Strange, it will attempt to debunk any considerations of a "declining" French influence in Francophone Africa. It will be argued that the existence of "special relationships" manifested through close political and cultural ties but also through covert economic and military networks give onto France the potentials to determine the structure of the regional political economy, in which Francophone African States evolve (hypothesis).

\section{KEYWORDS}

Structural Power; Francophone Africa; China. 